UNIVERSITY

OF DEBRECEN

FACULTY OF

HEALTH

NYíREGYHÁZA

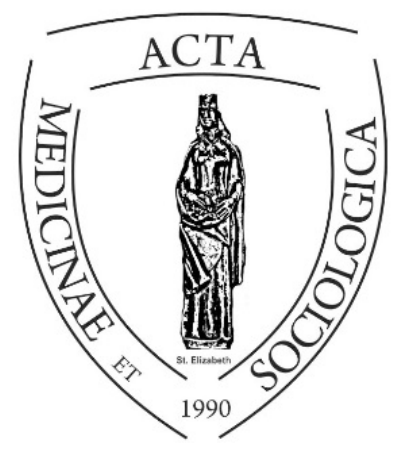

ACTA

MEDSoC

VOLUME 7.

2016

\title{
Közéleti aktivitás, helyi közösségről alkotott vélekedések és intergenerációs kapcsolatok a nyíregyházi ifjúság körében
}

\section{Public Activity, Opinions about Local Community, and Intergeneration Activities among Youth in Nyíregyháza}

\author{
Patyán László, Huszti Éva
}

\begin{abstract}
This study examines satisfaction with the town of Nyíregyháza among youth, as well as its public service provision, the quantity and the quality of the membership of public and community organizations. It also reveals young people's opinion about their intergenerational activities. Data are based on the "Youth of Nyíregyháza 2015" research.
\end{abstract}

Keywords: public activity, satisfaction with the town, satisfaction with public services, intergenerational connections.

DOI: $10.19055 / \mathrm{ams} .2016 .7 / 20-21 / 10$ 


\begin{abstract}
Absztrakt
A Nyíregyháza Ifjúsága 2015 kutatás eredményeire alapozva a tanulmány elsőként a nyíregyházi fiatalok közéleti aktivitását, ezen belül is a szervezett közösségekhez füződő kapcsolatait vizsgálja meg, majd a településsel kapcsolatos vélekedéseit elemzi. Nyitott kérdésekből kapott válaszok alapján, különböző kategóriákat kidolgozva mutatja be a fiatalok pozitív és negatív értékelését a városra vonatkozóan, majd sorolja fel változtatási javaslataikat. A dolgozat harmadik része a generációk együttélésével foglalkozik részletesebben.
\end{abstract}

Kulcsszavak: közéleti aktivitás, helyi szolgáltatásokkal való elégedettség, intergenerációs kapcsolatok

\title{
Bevezetés
}

A Nyíregyháza Ifjúsága 2015 címü kutatás keretében lehetőségünk volt feltárni, megismerni a helyi fiatalok közéleti aktivitását, a helyi közösségről alkotott vélekedéseiket, valamint a különböző generációk közös cselekvési területeit, annak gyakorlatát. Ezzel egyrészt követtük a Magyar Ifjúság kutatássorozat témáit, másrészt újat is hoztunk, hiszen figyelmet fordítottunk a fiatalok lokális közösséghez való viszonyára, valamint az intergenerációs kapcsolatok müködésére, a fiatal és az idősebb generációk kapcsolódási pontjaira. Tanulmányunk elsőként a nyíregyházi fiatalok közéleti aktivitását, a szervezett közösségekhez füződő kapcsolatait vizsgálja meg, majd a településsel és a települési közösségekkel kapcsolatos vélekedéseit elemzi. A dolgozat harmadik része a generációk együttélésével foglalkozik részletesebben.

\section{Módszer}

A Nyíregyháza Ifjúsága 2015 kutatásban két korcsoportot vizsgáltunk, a 15-18 éveseket, illetve a 19-29 éveseket. A mintáról, a mintavételi illetve az adatgyüjtési folyamatról részletesen lehet tájékozódni a kötet módszertani fejezetében (Huszti, Takács és Hüse, 2016). A kutatás során alkalmazott kérdőív első részében fogalmaztuk meg kérdéseinket a fiatalok közéleti aktivitásával kapcsolatban. Az országos kutatásban használt kérdést tettük fel mi is: „Kapcsolódik-e Ön valamilyen módon a következő szervezetekhez?’. Húsz különböző szervezetet soroltunk fel és kértük meg a fiatalokat arra, hogy mondják meg, tagjai-e a felsorolt szervezeteknek, részt vesznek-e munkájukban, elmennek-e néha a rendezvényeikre, vagy nem kapcsolódnak az adott szervezetekhez.

A helyi közösséggel kapcsolatos kérdéseinket a kérdőív utolsó részében helyeztük el. A közösségi életet a közösségi felmérés során általánosságban alkalmazott 
kérdések szerint tettük fel (Bihariné és mtsai, 1995), és olyan kérdések mentén vizsgáltuk, mint „Mióta él Ön a településen?”, „,Mit szeret az itteni életben?”, „Mi az, amit nem szeret, ami zavarja az itteni életben?”, „Mi az, amin szívesen változtatna?”.

A nyitott kérdések lehetőséget nyújtottak arra, hogy a válaszadók saját véleményük szerint fogalmazzák meg válaszaikat, s maguk állítsák fel azt a preferencia sorrendet is, melyek számukra a legégetőbb problémák, illetve a legfontosabb települési értékek.

A generációk együttmüködését négy kérdés mentén vizsgáltuk. Először is arra voltunk kíváncsiak, hogy milyen gyakran találkoznak a fiatalok olyanokkal, akiket ők idősként definiálnak. A válaszok a napi többszöri találkozás és a ritkábban, mint havonta gyakoriság között váltakozhattak. Megkérdeztük azt is, hogy hogyan, milyen módon kommunikálnak a fiatalok idősekkel. Itt a személyes találkozáson kívül a telefonos és az internet segítségével történő kapcsolattartás megjelölésére is lehetőség volt. Két nyitott kérdésben érdeklődtünk a fiataloktól arról, hogy általában milyen tevékenységeket szoktak végezni idősekkel együtt, illetve, hogy milyen tevékenységeket végeznének szívesen idősekkel együtt, milyen programokba, időtöltésekbe vonnák be őket. (A kutatás során alkalmazott kérdőívet a tanulmánykötet melléklete tartalmazza.)

\section{Települési közösség, mint erőforrás}

A települési közösségek funkcionalista megközelítése szerint a jól müködő és megfelelő megtartóképességű közösségeknek az alábbi funkcióknak kell megfelelniük: a közösség biztosítson megfelelő megélhetést tagjainak, elégítse ki a társasági igényt, nyújtson értéket a tagjainak, erősítse a közösségi kontrollt és tagjai kölcsönösen segítsék, támogassák egymást (Warren, 1957). E tekintetben a helyi közösség funkciói mit sem változtak, s a település és a települési közösség tagjai így az ifjú korosztály tekintetében is - komoly jelentőséggel bírnak. Ez határozza meg a korosztály megtartásának és kibocsátásának esélyét, s ez befolyásolja azt is, kik és miért maradnak az adott településen és miért érzik ott jól magukat.

Egy település lakosság megtartó képességét jelentősen befolyásolja az, hogy milyen esély nyílik a településen a megélhetésre, boldogulásra. A Magyar Ifjúság 2012 kutatás regionális adatelemzése szerint a munkahelykeresés tekintetében a Szabolcs-SzatmárBereg megyei fiatalok a legpesszimistábbak. Az Észak-Alföldi régió megyéit összevetve e megyében ítélik meg a 15-29 éves korosztály tagjai a legkedvezőtlenebbnek a munkaerő-piaci kínálatot. A megyében élők 80 százaléka tartja komoly problémának az elhelyezkedést, míg Hajdú-Bihar megyében 50 százalékuk, azaz az országos átlag, Szolnok megyében pedig 63,5 százalék ez az arány. Az ifjú korosztály 36 százaléka gondolja úgy, hogy sikeresen el tud helyezkedni az iskola befejezését követő hat hónapon belül. Ez az arány a legrosszabb a régióban (Szabó-Nagy, 2015). 
A település kulturális, szabadidős és egyéb társas együttlétet biztosító funkciója minden korosztály számára fontos. Ennek jellemző megnyilvánulási területei a formális szerveződések és természetes közösségek, ahol az emberek társasági életet élhetnek. A Magyar Ifjúság 2012 kutatás eredményei szerint a 15-29 év közötti korosztály egyre kisebb aktivitást mutat a formális szerveződések irányában. Míg az EU27-ek tagállamaiban 52 százalékos aktivitást mértek e területen, hazánkban ez az arány mindössze 40 százalék volt. Az ifjú korosztály szervezeti tagságai összefüggésében ez a harmadik legrosszabb adat, $\mathrm{s}$ a tendenciák folyamatosan romlanak. 2000-ben a korosztály 17 százaléka rendelkezett szervezeti tagsággal, 2004-ben már csak 15 százalékuk, 2008ban pedig már csak 6 százalék vett részt valamilyen szervezet életében. A Magyar Ifjúság 2012 kutatás adatai szerint legalacsonyabb aktivitás a politikai szerveződések életében figyelhető meg, a hivatkozott kutatás szerint érdemben nem is volt mérhető a politikai szerveződésekben tagsággal bírók aránya. Legmagasabb arányban a sport szerveződésekhez kapcsolódtak a fiatalok (5\%), ezt a diákszervezetek (4 \%), majd a szabadidő szervezéssel foglalkozó szervezetek követték (2\%) (Szabó-Nagy, 2015).

\section{Közéleti aktivitás - kapcsolódás különböző szervezetekhez}

A közéleti és közösségi aktivitás egyik lehetősége, ha az egyén különbözö közösségi szerveződésekben vállal részt. Az ifjú korosztály formális szervezetekhez való kötődésének hiánya a hazai kutatások alapján is komoly kihívásokat hordoz.

1. sz. táblázat: A városi ifjúság közéleti aktivitása

\begin{tabular}{|l|r|r|r|r|r|r|r|r|}
\hline & \multicolumn{2}{|c|}{$\begin{array}{c}\text { tagja } \\
(\%)\end{array}$} & \multicolumn{2}{c|}{$\begin{array}{c}\text { részt vesz } \\
(\%)\end{array}$} & \multicolumn{2}{c|}{$\begin{array}{c}\text { néha megy } \\
\text { rendezvényre } \\
(\%)\end{array}$} & \multicolumn{2}{c|}{$\begin{array}{c}\text { nem } \\
\text { kapcsolódik } \\
\text { sehová } \\
(\%)\end{array}$} \\
\hline & $15-18$ & $19-29$ & $15-18$ & $19-29$ & $15-18$ & $19-29$ & $15-18$ & $19-29$ \\
\hline diák-szervezet & 21 & 10 & 9 & 4 & 16 & 5 & 54 & 81 \\
\hline $\begin{array}{l}\text { szabadidős } \\
\text { szervezet }\end{array}$ & 23 & 6 & 5 & 3 & 16 & 7 & 56 & 84 \\
\hline $\begin{array}{l}\text { kulturális, stb. } \\
\text { müv.csop. }\end{array}$ & 18 & 4 & 5 & 2 & 11 & 6 & 66 & 88 \\
\hline sport & 32 & 8 & 7 & 2 & 8 & 8 & 53 & 82 \\
\hline $\begin{array}{l}\text { körny.véd. } \\
\text { állatvéd. }\end{array}$ & 8 & 4 & 5 & 2 & 13 & 5 & 74 & 89 \\
\hline $\begin{array}{l}\text { lelki, } \\
\text { szoc.probl-val } \\
\text { fogl. szerv. }\end{array}$ & & 3 & 1 & 2 & 5 & 3 & 85 & 92 \\
\hline jótékonysági & 7 & 5 & 4 & 1 & 16 & 5 & 73 & 89 \\
\hline egyházi & 12 & 5 & 2 & 1 & 8 & 3 & 78 & 91 \\
\hline
\end{tabular}




\begin{tabular}{|l|r|r|r|r|r|r|r|r|}
\hline emberjogi & 8 & 4 & 4 & 1 & 4 & 3 & 84 & 92 \\
\hline békemozg. & 8 & 3 & 3 & 1 & 4 & 3 & 85 & 93 \\
\hline szakszervezet & 7 & 3 & 3 & 1 & 3 & 1 & 87 & 95 \\
\hline $\begin{array}{l}\text { szakmai } \\
\text { egyesület }\end{array}$ & 8 & 3 & 1 & 1 & 4 & 3 & 87 & 93 \\
\hline $\begin{array}{l}\text { más } \\
\text { érdekvédelmi }\end{array}$ & 7 & 3 & 1 & 1 & 4 & 2 & 88 & 94 \\
\hline polgári ifjúsági & 7 & 4 & 2 & 1 & 6 & 1 & 85 & 94 \\
\hline $\begin{array}{l}\text { más ifjúsági } \\
\text { szervezet }\end{array}$ & 9 & 3 & 3 & 1 & 5 & 3 & 83 & 93 \\
\hline politikai párt & 8 & 3 & 1 & 1 & 2 & 2 & 89 & 94 \\
\hline polgári kör & 7 & 4 & 2 & 1 & 3 & 1 & 88 & 94 \\
\hline polgárörség & 8 & 3 & 4 & 1 & 2 & 2 & 86 & 94 \\
\hline határon túli & 12 & 3 & 1 & 1 & 4 & 1 & 83 & 95 \\
\hline
\end{tabular}

Forrás: Nyíregyháza Város Ifjúsága 2015. kutatás

Az összminta 68,5 százaléka nem tagja semmilyen szervezetnek. Valamilyen tagság így csupán 32,5 százalékukra jellemző, ami alacsonyabb az egyébként is nagyon alacsony országos eredményekhez viszonyítva is, ahol a 2012-es Magyar Ifjúság kutatás szerint a vizsgált korcsoport 40 százaléka mutatott valamiféle szervezeti aktivitást (Székely, 2013).

Az országos kutatásban a sportegyesületekhez való tartozás a leggyakoribb, majd azt követi a diák- és hallgatói szervezetek tagsága, aztán a szabadidős szervezetek (Székely, 2013). A nyíregyházi fiatalok körében is hasonlóan alakult a sorrend: 16 százalékuk tagja valamilyen sportklubnak vagy szervezetnek, 13,5 százaléka valamilyen diákszervezetnek, és 11,5 százaléka valamilyen szabadidős szervezetnek.

A 15-18 évesek 48 százaléka, az idősebb korcsoportnak viszont 78,5 százaléka nem kapcsolódik semmilyen szervezethez. Legalább egy szervezetnek tagja minden ötödik fiatal (22,5\%), míg ez csak minden tízedik (13\%) idősebbre jellemző. A több szervezethez való tartozás a 15-18 évesek harmadára (30 \%), míg a 19-29 évesek mintegy 10 százalékára jellemző. A korcsoportok közötti eltérés szignifikáns $(p=0,000)$.

A formális szervezetekhez való tartozás jellemzően az iskolarendszeren keresztül valósulhat meg, míg a rendszerből kilépve csökkent a szervezetekhez való kapcsolódás, illetve a tagság esélye. Úgy is mondható, hogy egy „légüres térbe” lépnek ki a fiatalok, ahol tízből egy főnek van valamilyen szervezethez és az ott müködő közösséghez kötődése. Ezek az eredmények azt mutatják, hogy hosszútávon érvényesülő folyamatokról van szó, ugyanis egy, a városban 1988-ban folytatott, a fiataloknak a helyi cselekvésben és közéletben vállalt szerepe, és az azokhoz kapcsolódó elvárások, valamint értékek szük két évtized alatt sem változtak lényegesen. A fiatalok a 
kilencvenes években a közvetlenebb társadalmi környezetükért cselekedtek aktívan, a „(nagy)politika” kevésbé vonzotta őket (Fónai-Fábián, 1999, Fónai-Fábián, 2000).

\section{Fiatalok a helyi közösségről}

\section{A város kedveltsége - „Mit szeret az itteni életben?”}

A válaszadók által a nyitott kérdésre adott számtalan opciót tartalmuk alapján néhány főbb dimenzióba rendeztük, melyek gyakoriságát az 1. sz. ábra mutatja be.

A ,szoros kapcsolatok” dimenzióba kerültek azok a válaszok, melyek esetében a szülők, a család, vagy a barát(nő) közelségét tekintették a válaszadók a város legfontosabb vonzerejének. A „laza kötésủ kapcsolatok” kategóriába a haverok, iskolai társak jelenlétét megjelölő válaszok kerültek. Az ún. „lokálpatrióta” dimenzió azokat a válaszokat foglalja magába, ahol a legfontosabbnak a város szépségét, csendességét, a Sóstó szépségét stb. megjelölő opciók kerültek. A „szolgáltatások” kategória a fiatalok által értékkel bíró szolgáltatásokat tartalmazó válaszokat tartalmazza, de ezek közül kiemeltünk két jellemzőt, az oktatási és munkalehetőségeket megjelenítő dimenziókat.

1. sz. ábra: Mit szeret Nyíregyházán? (N15-18=147; N19-29=296). (\%)

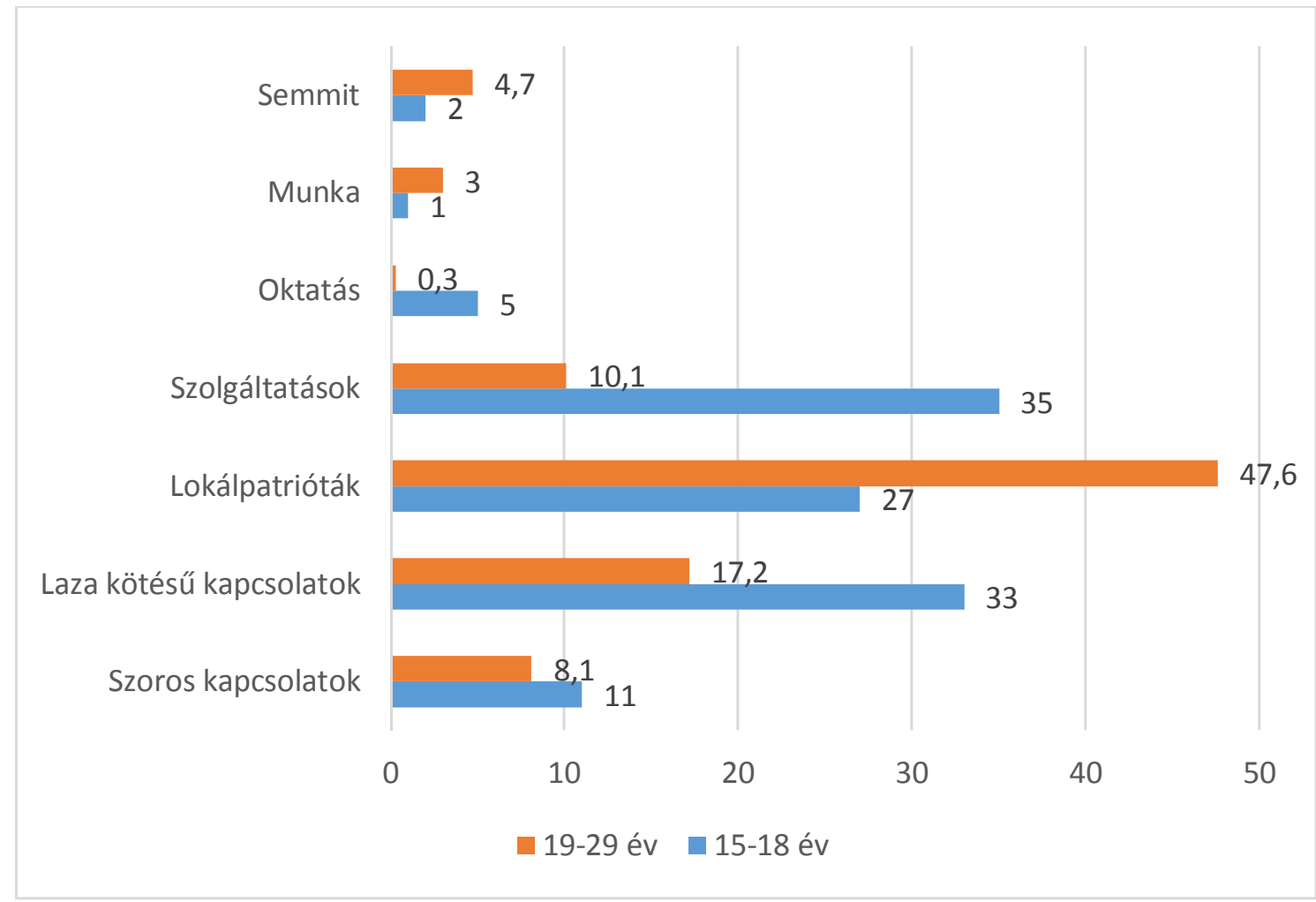

Forrás: Nyíregyházi ifjúságkutatás 2015. Megjegyzés: a nem értékelhető válaszok nem kerültek elemzésre. 
Az ifjú korcsoportot a legtöbb kapcsolattal rendelkező csoportként tartjuk nyilván, ennek ellenére a városi életminőség kutatás (Fábián, Patyán, Huszti, 2012; Huszti-Patyán-Fábián, 2014; Huszti, 2015) eredményei szerint a korosztályt is jellemzi a baráti kapcsolatok számának csökkenése. A Nyíregyháza Életminősége adatfelvételek alapján megállapítható, hogy a városban a fiatal korosztály tagjai körében csökkent a barátok száma leginkább.

Jelen kutatásban a kérdöív vonatkozó, nyitott kérdésére a 15-18 év közötti válaszadók majd' kétszer nagyobb aránya (33\%) említette a város vonzereje kapcsán azt, hogy itt élnek barátai, haverjai. Ez a ráta a 19-29 éves korosztály körében lényegesen alacsonyabb (17\%).

\section{A város élhetősége, szolgáltatások}

A város élhetősége és kedveltsége meglepő módon a leggyakrabban említett válasz volt a 19 év fölötti válaszadók körében. A válaszadók majdnem fele nevezett meg valamilyen településsel kapcsolatos jellemzőt, amiért szeret itt élni (zöldterületek, felújítások, urbánus légkör, csendesség, tisztaság, Sóstó stb.). E korcsoport a település megyeszékhely jellegét, a város építészetét és az itteni élet ritmusát tekintik legfontosabb jellemzőnek. Szorosan ehhez a dimenzióhoz kötődnek a településen igénybe vehető szolgáltatások. A fiatalok jellemzően a fogyasztási, szabadidős, sport, közlekedési és kulturális szolgáltatásokat jellemezték a kérdés mentén. A fiatalabb korosztály sokkal inkább tekint a településre, mint olyan városra, ahol a szolgáltatások jobban elérhetők, mint más településeken. Ez némiképp összefüggést mutat a kérdezés módszerével - az iskolában tanuló korosztály egy része a szolgáltatásokkal szerényebben ellátott megyei kistelepülésekről származhat, így a város szolgáltatásait (sport, bevásárlás, szabadidő) sokkal kedvezőbben ítélik meg. A szolgáltatások körében külön elemeztük az oktatási lehetőségeket és a munkalehetőségek elérhetőségét. E témákat azonban jellemzően kevesen tekintették kiemelkedő jelentőségünek a város megítélésében.

\section{Mit nem szeret a városban?}

A legkevésbé kedvelt jellemzők szintén eltéréseket mutatnak a korcsoportok között. 
2. sz. ábra: Mit nem szeret a városban? (N15-18=129, N19-29=237) (\%)

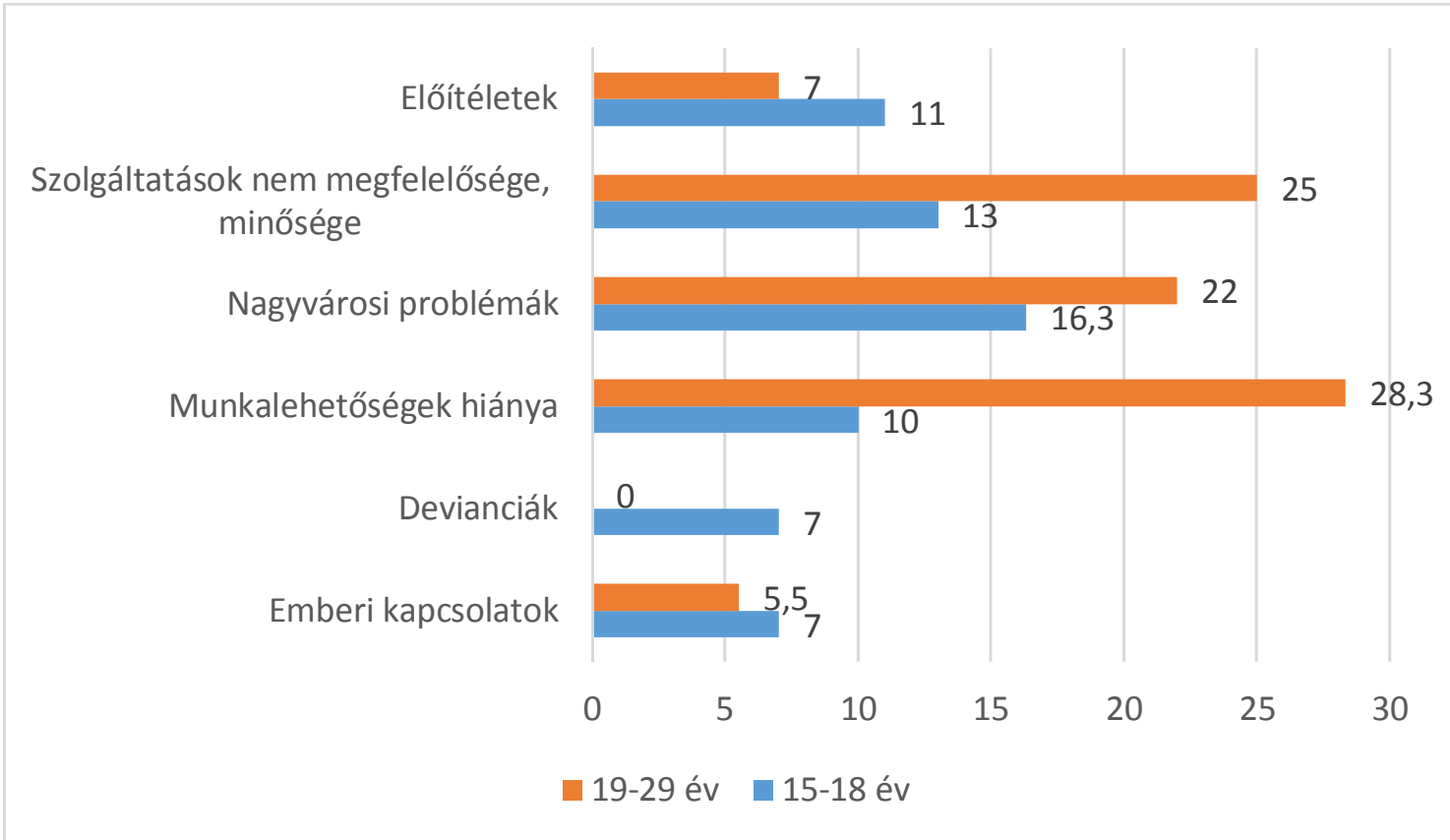

Forrás: Nyíregyházi ifjúságkutatás 2015.

Megjegyzés: a nem értékelhető válaszok nem kerültek elemzésre.

A városban legkevésbé kedvelt dolgok között számos olyan jellemzőt találunk, melyek a korosztály társas kapcsolatait, valamint közösségi viszonyait, biztonságát jellemzik, illetve ezek leképeződéseiként jelentkeznek a korcsoport válaszaiban. Külön változóként elemeztük az emberi kapcsolatokkal összefüggésben megjelent válaszokat (az emberek ,bunkók”, nem segítenek, távolságtartók, nem befogadók stb.). Ilyen típusú válaszokat adott a fiatalabb korosztály 7 százaléka és az idősebbek 5,5 százaléka. Az emberi és a társas kapcsolatokkal való elégedetlenség mindenképp fontos üzenetértékkel bír e korosztály jólléte, közösségi integrációja tekintetében.

A fiatalok a devianciák jelenlétét is problémaként jelezték. Jellemzően ez a 15-18 év közötti korosztály esetében volt jellemzőbb. E korosztály 7 százaléka tekintette az alkohol-, a drogfogyasztást, a bünözést, vagy a magatartási problémákat a legfontosabb kérdésnek. A 19 év fölötti korosztály e problémát nem említette a leglényegesebbek között.

A kutatás során sor került egy „elöítéletek” változó kialakítására is. Ide soroltuk azokat a megjegyzéseket, ahol a válaszadó egy-egy célcsoport negatív jellemzőit emelte ki problémaként (pl. romák, cigányok, sok cigány, dologtalan cigányok, hajléktalanok, sok hajléktalan, nyugdíjasok stb.). Ezen esetekben a válaszadók a célcsoport létét emelték ki elsősorban problémaképpen. A fiatalabb korcsoport 
esetében magasabb volt azok aránya, akik e problémákat tekintették legfontosabb jellemzőnek (11\%), míg az idősebbek esetében csökkent ennek a jelentősége (7 \%). A Magyar Ifjúság 2012 kutatás vonatkozó eredményei szerint a fiatalabb korosztály körében jellemzőbb a normakövetés igénye (Székely, 2013), ezzel magyarázható a devianciákkal kapcsolatos érzékenység. Mindenesetre a fenti jellemzők arra engednek következtetni, hogy a 15-18 éves korosztály körében jelentőséggel bírhatnak az érték nyújtó, preventív, társadalmi problémákat elemző programok, melyekre szenzitívebben reagál még e célcsoport.

A város urbánus jellegéből adódó problémák paradox módon épp annak a célcsoportnak (19-29 év közöttiek) jelentenek nagy problémát, akik e jellemzők miatt szeretik legjobban Nyíregyházát. Minden ötödik válaszadónak van valamilyen gondja a városi léttel (pl. túl zajos, koszos, nem fejlődik eléggé, túl csendes, szmog van, zöldövezet hiánya stb.), de a válaszok gyakran egymással ellenétes értelmüek (túl zajos, túl csendes), mindenesetre a fiatalok fontosnak tartják a város fejlődését.

A városban elérhető szolgáltatásokkal való elégedettség is megosztja a vizsgált korcsoportokat. A fiatalabbak, akik elégedettebbek a településen kínált szolgáltatásokkal, ebben az esetben kevésbé kritikusak, szemben a 19 év feletti városlakókkal, akik közül minden ötödik válaszadó a szolgáltatások hiányosságait nevezte meg fö problémaként. Meglepő módon a közszolgáltatások közül a tömegközlekedés kapta a legtöbb kritikát, a szolgáltatásokkal elégedetlenek majd' fele ezt jelölte meg kritikaként. A válaszadók szerint a tömegközlekedés a településen nem városias, ritka, nem igazodik az igényükhöz. ${ }^{31}$ A kritikusok másik fele a szabadidős és kulturális szolgáltatások hiányát emelik ki. A Magyar Ifjúság kutatás regionális adatai szerint Szabolcs-Szatmár-Bereg megyében volt a legmagasabb a kultúrafogyasztók aránya (Nagy-Székely, 2015). A megyeszékhelyen nyilván még erősebb ez a preferencia.

A munkalehetőségek, a boldogulás hiánya a fiatalabb korosztály 10 százalékát, míg a 19 év felettiek 28 százalékát foglalkoztatja leginkább. Ahogy ezt már korábban is jeleztük, megyénk a legrosszabb mutatókkal rendelkezik a fiatalok munkakezdési esélyeit illetően (Nagy-Székely, 2015). A városi adatok ennél kedvezőbb képet mutatnak, de ennek ellenére majdnem minden harmadik 19 év feletti válaszadó ezt említette a legsúlyosabb gondként.

\footnotetext{
${ }^{31}$ Megjegyzés: A korcsoport körében végzett fókuszcsoportos vizsgálat egyik eredménye szintén a tömegközlekedés rossz állapotának felvetése volt.
} 
3. sz. ábra: Lehetösége szerint min változtatna leginkább?

$(N 15-18=73, N 19-29=221)(\%)$

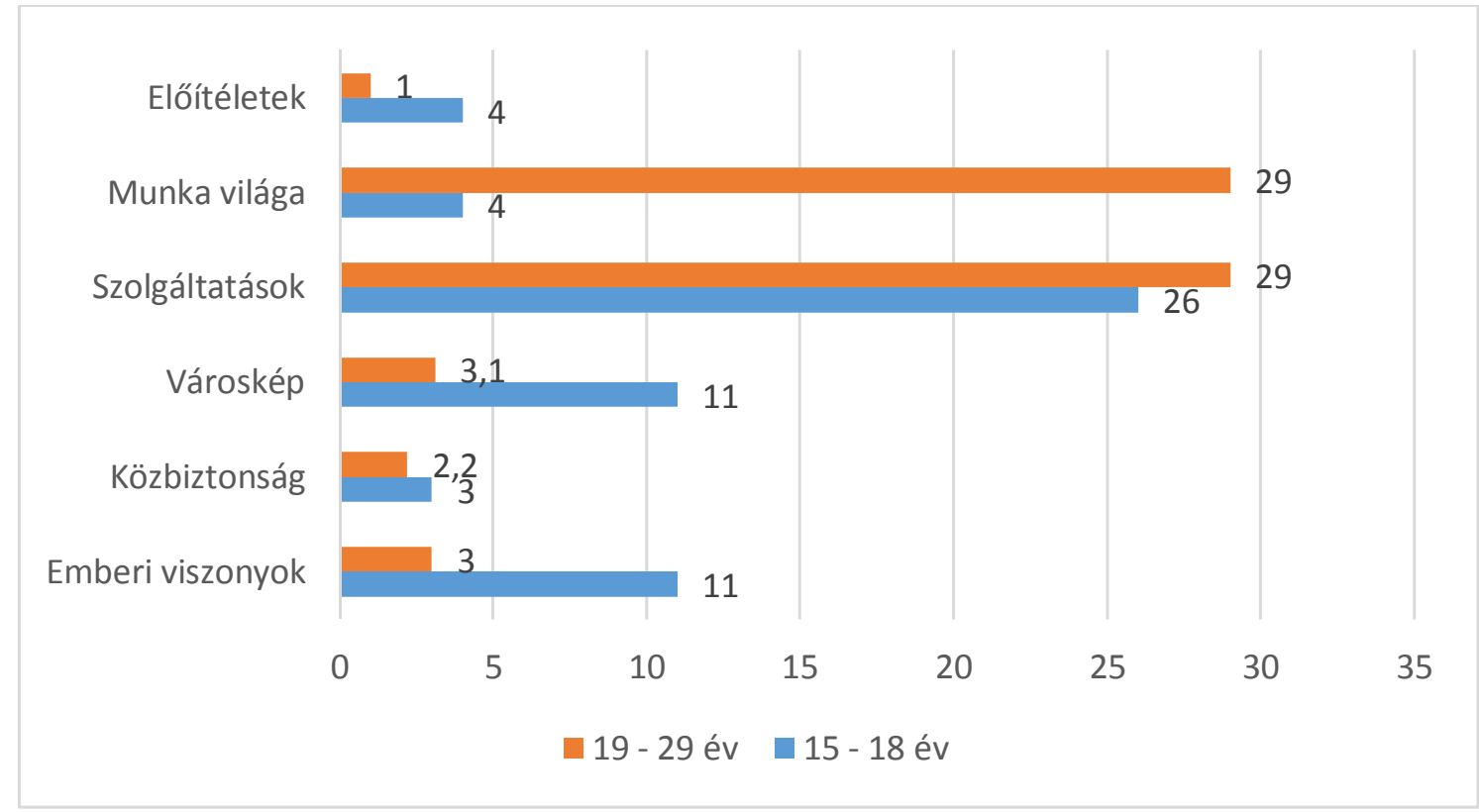

Forrás: Nyíregyházi ifjúságkutatás 2015.

Megjegyzés: a nem értékelhető válaszok nem kerültek elemzésre.

Arra a kérdésre, hogy a fiatalok mely dolgokon változtatnának leginkább, jellemzően olyan válaszokat kaptunk, melyek arra utalnak, hogy melyeken kellene megítélésük szerint változtatni, és nem olyanokat, hogy ők maguk milyen változtatási folyamatokban vennének részt. A válaszok egy része nem realisztikus, inkább kívánalom (pl. az elöítéletekkel kapcsolatban: kevesebb roma kellene). A 1518 év közötti korosztály esetében erős a vágy az emberi kapcsolatok és viszonyok megváltoztatása irányában (11\%), és két-három százalékban megjelent a jobb közbiztonság iránti igény is. Jobb szolgáltatásokat a fiatalabb korosztály 26 százaléka, míg az ifjú városlakók 29 százaléka szeretne. A szolgáltatások körében azonban a kulturális eseményeken túl megjelentek a jobb oktatási intézmények és természetesen a tömegközlekedés javításának igénye is. A 19 év feletti korosztály esetében legfontosabb a szolgáltatások körében a tömegközlekedés, a lakhatás, illetve lakáshoz jutás, valamint a kulturális és szórakozási lehetőségek szerepeltek fontossági sorrendben.

A fiatalabbak négy százaléka, a 19 év felettiek 29 százaléka említette a munka világát, mint olyan területet, ahol változtatni kellene. Elsősorban több munkalehetőséget, valamint megfelelő módon fizetett állásokat szeretnének, valamint nagyobb biztonságot a munkaeröpiacon.

Összességében megállapítható, hogy a fiatalabb korosztály érzékenyebbnek mutatkozik a társadalmi problémák iránt, $\mathrm{s}$ fontos számukra a városban elérhető szolgáltatások mennyisége és minősége egyaránt. A 19 év feletti korosztály 
tekintetében az élet kezdésével kapcsolatos kérdések jelentősége nő, különös tekintettel a létbiztonságra, a megfelelő és megfizetett munkára, a lakásszerzésre. A városi szolgáltatások mellett fontos számukra a település fejlődése, a városkép, illetve az épített infrastruktúra. A közszolgáltatások körében mindkét csoport a tömegközlekedés minőségével és mennyiségével a legkevésbé elégedett.

\section{Intergenerációs viszonyok}

Az aktív idősödés és nemzedékek közötti szolidaritás megközelítésének egyik fontos kérdése, hogy lehet-e a generációs előítéleteket csökkenteni, illetve miként lehet az ifjúság és az időskorú generáció kapcsolatát elősegíteni? Az országos nagymintás ifjúságkutatások erre a témakörre nem koncentráltak, így a fiatalok generációs kapcsolatairól összevethető adatokkal nem rendelkezünk, ezért tartottuk fontosnak a generációk közötti kapcsolatok elemzését jelen kutatás keretein belül.

A generációk kapcsolatának egyik lehetősége a közös programok, tevékenységek megvalósítása. A nyitott kérdésekre adott válaszok közül öt kategóriát alakítottunk ki. A „beszélgetés” kategória arra vonatkozik, amikor a válaszadó közös tevékenységként ezt tudta megjelölni. A „,közös aktivitások otthon” csoportba azokat a tevékenységeket rendeztük, ahol a tevékenység az időskorú otthonában történik. A harmadik csoportot azon tevékenységek alkották, ahol az idősek és fiatalok nem otthon töltik együtt az idejüket. Ezen kívül a „semmit” és a „segítségnyújtás” változókat alakítottuk ki.

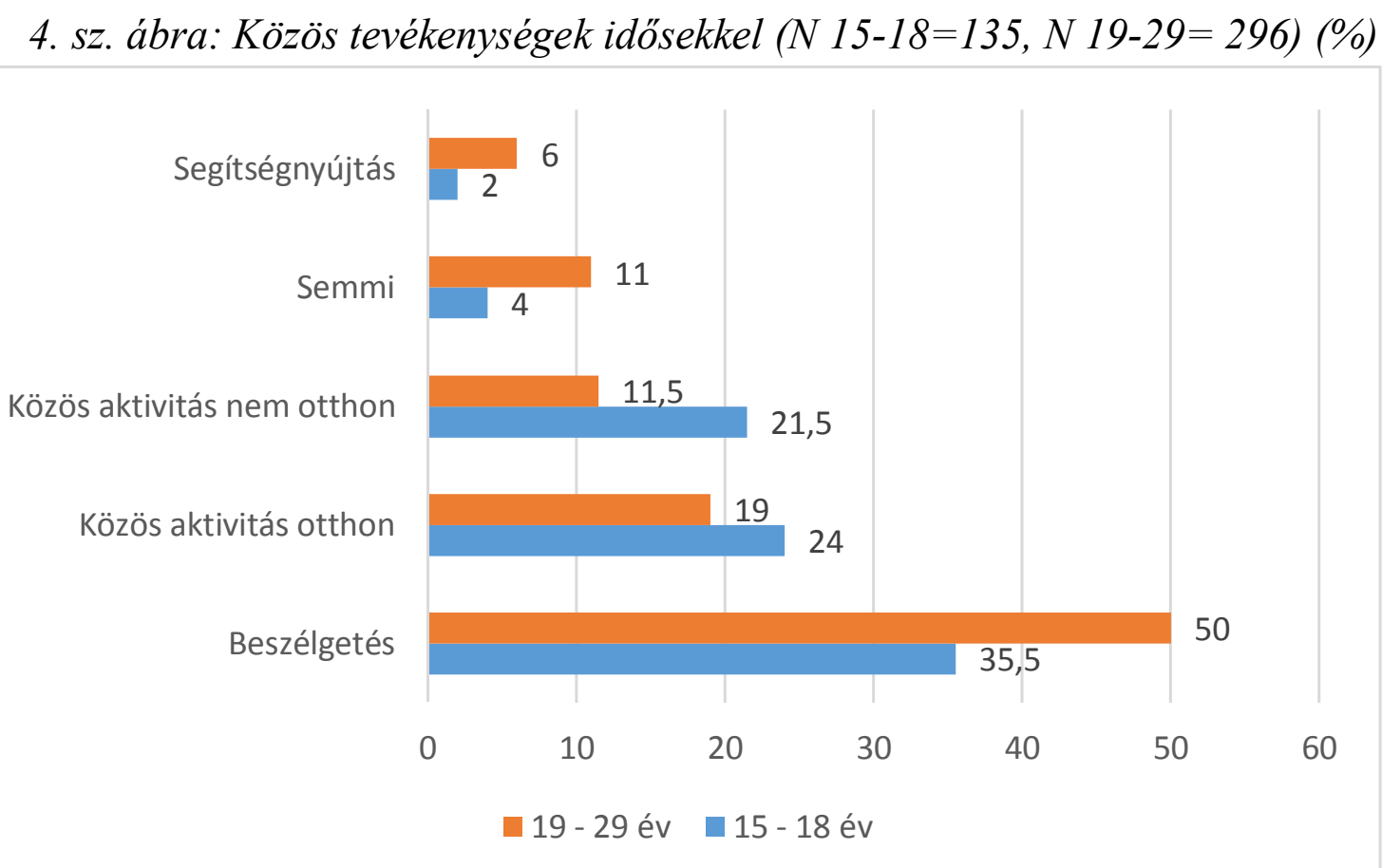

Forrás: Nyíregyháza Város Ifjúsága 2015. kutatás 
A szokásos, hagyományos együttlét formái közül a beszélgetés a legjellemzőbb. A 19 év felettiek fele, míg a fiatalabb korosztály harmada számolt be ilyen aktivitásokról. A második leggyakoribb tevékenység olyan közös programok végzése, melyek az időskorú otthonához kötődnek. A 15-19 évesek ötöde, a 19 év felettiek hatoda számolt be ilyen tevékenységekröl (közös fözés, kerti munka, kártyajáték, Internet tanulása stb.). Házon kívüli programokat jellemzőbben a fiatalabb korosztály tervez. E tevékenységek jellemző többsége a szabadidő, az utazás és a sport területén jelent közös tevékenységet generációk között.

A fiatalabb korosztályban nem bír még jelentőséggel, de a 19 év feletti fiatalok körében megjelenik még egy közös tevékenység, az idősek segítése, gondozása (6 \%). A válaszokból nem derül ki világosan, hogy a fiatalok a segítségnyújtást, mint hivatást, vagy mint rokoni szolidaritáson alapuló tevékenységet végzik.

5. sz. ábra: Milyen tevékenységekbe vonná be az idöseket?

$$
(N 15-18=135, N 19-29=198)(\%)
$$

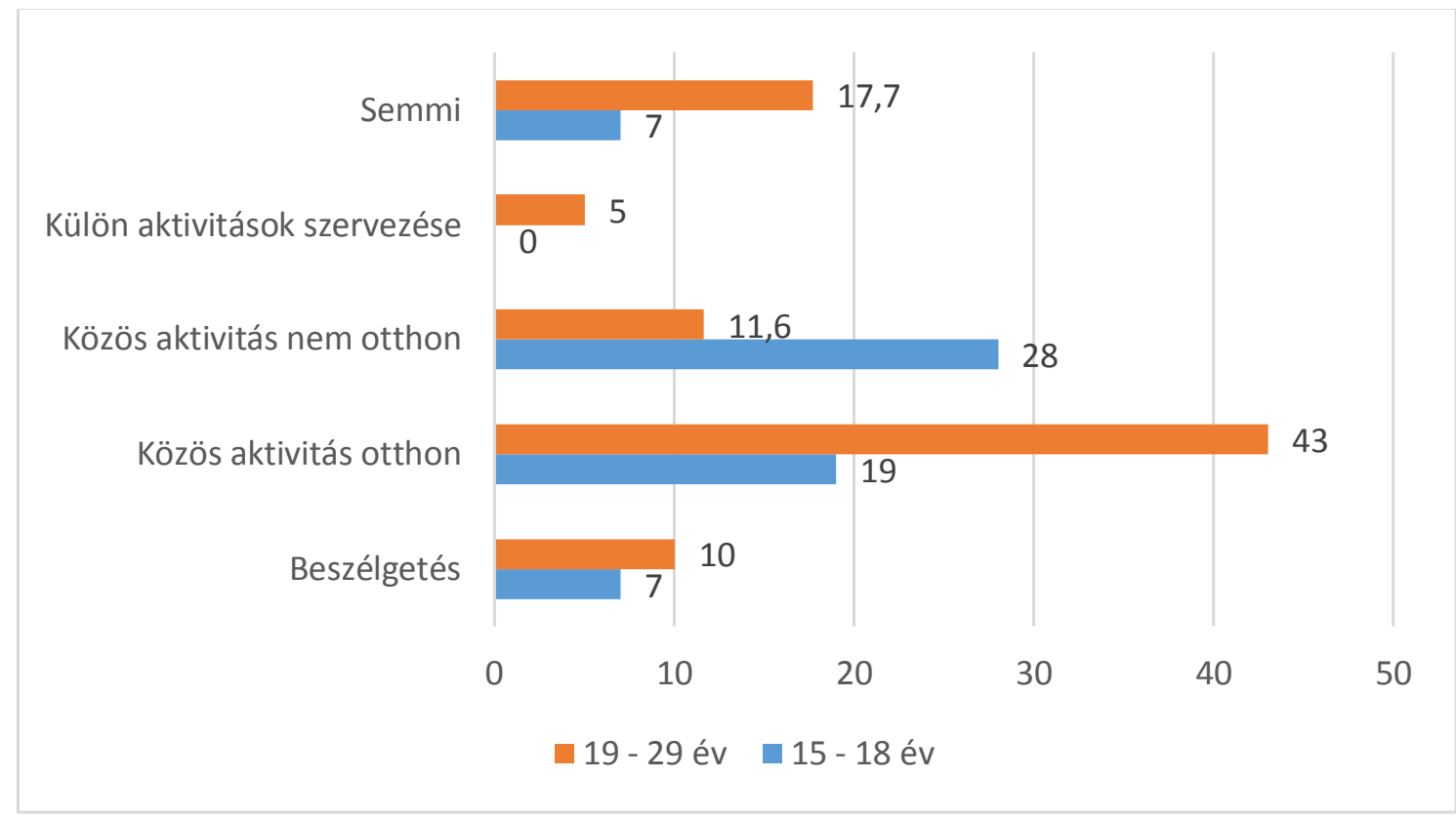

Forrás: Nyíregyháza Város Ifjúsága 2015. kutatás

Az idősek közös tevékenységekbe való bevonását a közös aktivitás mintázatai szerint képzelik el a fiatalok. A 19 év feletti korosztály lényegében az otthoni közös programokat fejlesztené, míg a fiatalabb korosztály a házon kívüli közös tevékenységeket helyezné előtérbe. Érdekes módon megjelent az idősekkel kapcsolatos programok egy olyan dimenziója is, mely esetében a fiatal nem vesz részt közvetlenül a közös aktivitáson (5\%). Ez esetekben beíratnák valahova az időskorút, vagy elvinnék a klubba, azaz a cél nem a közös tevékenység elérése, sokkal inkább a gondoskodás, mint a felelösség személytelenebb megszervezési formája dominál. 


\section{Összegzés}

E tanulmányban a városi ifjú korosztály települési közösséggel való elégedettségét, szervezeti kapcsolatrendszereit és az idősebb generációval való kapcsolatát vizsgáltuk meg. A kérdőív nyitott kérdéseinek elemzése lehetőséget nyújtott arra, hogy a fiatalok az általuk értékesnek tartott válaszokat saját maguk definiálhassák. Elemzésünket jórészt e válaszok értelmezése útján nyerhettük. A kutatás ezen elemének vizsgálata jó alapot nyújthat beavatkozási irányok és módszerek tervezésére a városi ifjúság körében és körülrajzolta mindazokat a problémákat, melyekre a két vizsgált életkori csoportban és mintában koncentrálni lehet.

A két korosztály megbontása a kutatás tapasztalatai szerint mindenképp indokoltnak tekinthető. A 15-18 éves tanuló korcsoport más értékrenddel és más fogyasztási preferenciákkal rendelkezik, társas kapcsolataikat és jövőképüket is más értékek határozzák meg.

A 15-18 év közötti fiatalokat elsősorban baráti kötelékeik kötik a városhoz, és jellemzően fontos számukra az érdeklődési körüknek megfelelő szolgáltatások elérhetősége. A 19 év feletti korosztály a lakás, a munka világa kérdéseire érzékeny és figyelemmel kíséri a település sorsát, a fejlődéssel kapcsolatos fejleményekre érzékenyen reagál. A válaszok szerint az ifjú korosztályt érintő kérdésekre a célcsoport tagjai maguk is megoldásokat remélnek, de a kutatás során úgy tủnt, nem érzik magukat cselekvő, aktor szerepben e kérdésekben.

A kutatás társadalmi szervezeti tagsággal kapcsolatos elemzése az országos tendenciáknak megfelelő képet nyújtott. A fiatalok alapvetően kevés társadalmi szerveződésnek tagjai, de társadalmi aktivitásuk az iskolarendszer elhagyásával még inkább csökken.

Az idősekkel való kapcsolatot a 15-18 év közötti korosztály közelíti meg „rugalmasabban”, több esélyt adva a kimozdulásra, közös aktív tevékenységre az idősekkel, így a települési intergenerációs programok fö szereplöje e célcsoport lehet. A 19 év felettiek a hagyományos szerepekben és aktivitásokban képzelik el az idősekkel való tevékenységeket.

\section{Felhasznált irodalom}

1) A nyíregyházi járás életminősége 2015. Szerkesztette: Huszti Éva. Acta Medicinea et Sociologica. Vol.6.No.18-19. 2015. Debreceni Egyetem Egészségügyi Kar, Nyíregyháza.

2) Életminőség Nyíregyházán. Szerkesztette: Fábián Gergely - Patyán László - Huszti Éva. Debreceni Egyetem Egészségügyi Kar, Nyíregyháza 2012.

3) Életminőség Nyíregyházán 2012. Szerkesztette: Huszti Éva - Patyán László-Fábián Gergely. Acta Medicinea et Sociologica. Vol.5.No.12-13. 2015. Debreceni Egyetem Egészségügyi Kar, Nyíregyháza. 
4) Bihariné Asbóth Emőke, Groskáné Pizásri Irén, Hallgató Éva, Kecskeméthyné Selidi Lilla, Keresztesi József, Magyar Istvánné, Mészáros Zsuzsa, Pálinkás Sándorné, Péterfi Ferenc, Pósfay Péter, Pocsainé Fábián Magda, Szolnoki Ildikó, Varga Matild, Boldoczi Éva, Böhm Emőke, Farkas Éva, Németh Ernő, Schmidt Melinda, Huszerl József, Varga Tamás, Vercseg Ilona: A helyi közösségfejlesztés folyamatairól a közösségi felmérés kapcsán. Parola, 1995. 6. sz. 1 - 25.

5) Fónai M - Fábián G: Célok, helyi cselekvés és helyi politikai részvétel nyíregyházi fiatalok körében. In: Fónai M - Mankó M (szerk.): Acta Inter Urbes. Szombathely: Berzsenyi Dániel Főiskola Müvelődéstudományi és Kommunikáció Tanszéke, 2000. pp. 89-127. (ISSN 1586 - 7994)

6) Fónai Mihály - Fábián Gergely: Nyíregyházi fiatalok politika és demokrácia képe. In: Rozgonyi I (szerk.): A demokrácia 10 éve. V. Politológus Vándorgyülés. Nyíregyháza: Nyíregyházi Főiskola Politológia és Szociológia Tanszéke, 1999. pp. 112-122. (ISBN 963913072 9)

7) Magyar Ifjúság 2012. Szerkesztette: Székely Levente. Kutatópont Kft., 2013.

8) Harmadrészt - Magyar Ifjúság 2012. Szerkesztette: Nagy Ádám - Székely Levente. ISZT Alapítvány - UISZ Alapítvány - Excenter Kutatóközpont, 2015.

9) Huszti É., Takács P., Hüse L. (2016): A „Nyíregyháza Ifjúsága 2015” kutatás módszertana. Acta Medicinae et Sociologica Vol. 7. No. 20-21: 211-218. oldal

10) Szabó Fanni - Nagy Zita Éva (2015): Észak-Alföld - Regionális Ifjúsági Helyzetelemzés. In: Harmadrészt - Magyar Ifjúság 2012 (Szerk. Nagy Ádám, Székely Levente), ISZT Alapítvány - UISZ Alapítvány - Excenter Kutatóközpont, 2015. pp. 117-149.

11) Warren, R.L.(1957): Towards a Reformulation of Community Theory In Human Organisation, vol. XV.pp. 8-11.

\section{A szerzők}

Patyán László főiskolai docens

Debreceni Egyetem Egészségügyi Kar, 4400 Nyíregyháza, Sóstói u. 2patyan.laszlo@foh.unideb.hu

Huszti Éva PhD föiskolai docens

Debreceni Egyetem Egészségügyi Kar, 4400 Nyíregyháza, Sóstói u. 2huszti.eva@foh.unideb.hu 